\title{
Should I Stay or Should I Go? Ephs and Ephrins in Neuronal Migration
}

\author{
Jennifer Rodger ${ }^{\mathrm{a}}$ Lorena Salvatore $^{\mathrm{b}}$ Paolo Migani ${ }^{\mathrm{c}}$ \\ ${ }^{a}$ Experimental and Regenerative Neurosciences, School of Animal Biology M317, University of Western Australia, \\ Crawley, W.A., Australia; ${ }^{b}$ Laboratorio del Metabolismo Lipidico e Tumorale, Consorzio Mario Negri Sud, \\ Santa Maria Imbaro, and ' Dipartimento di Biochimica, Biologia e Genetica, Università Politecnica delle Marche, \\ Ancona, Italy
}

\section{Key Words}

Cortex $\cdot$ Lamination $\cdot$ Neural progenitor $\cdot$ Rostral migratory stream $\cdot$ Olfactory bulb

\begin{abstract}
In neuroscience, Ephs and ephrins are perhaps best known for their role in axon guidance. It was first shown in the visual system that graded expression of these proteins is instrumental in providing molecular coordinates that define topographic maps, particularly in the visual system, but also in the auditory, vomeronasal and somatosensory systems as well as in the hippocampus, cerebellum and other structures. Perhaps unsurprisingly, the role of these proteins in regulating cell-cell interactions also has an impact on cell mobility, with evidence that Eph-ephrin interactions segregate cell populations based on contact-mediated attraction or repulsion. Consistent with these studies, evidence has accumulated that Ephs and ephrins play important roles in the migration of specific cell populations in the developing and adult brain. This review focusses on two examples of neuronal migration that require Eph/ephrin signalling - radial and tangential migration of neurons in cortical development and the migration of newly generated neurons along the rostral migratory stream to the olfactory bulb in the adult brain. We discuss the challenge involved in understanding how cells determine whether they respond to signals by migration or axon guidance.

Copyright $\odot 2012$ S. Karger AG, Basel
\end{abstract}

\section{KARGER}

Fax +4161306 1234

E-Mail karger@karger.ch

www.karger.com (c) 2012 S. Karger AG, Basel

$1424-862 X / 12 / 0203-0190 \$ 38.00 / 0$

Accessible online at:

www.karger.com/nsg

\section{Ephs and Ephrins in Neuronal Migration}

Cell migration is a key process in nervous system development, requiring precisely coordinated movements in time and space [1]. Most newly generated neurons, both during development and in the adult brain, arise from the proliferative epithelium surrounding the ventricles known as the ventricular zone. They then adopt either radial (towards the pial surface) or tangential (other directions) modes of migration to reach their final destinations within the central nervous system. The key cellular and molecular events that mediate migration are reviewed elsewhere [1] and will not be described here in detail. The focus of this review is to bring together recent studies describing the role of Eph/ephrins in neuronal cell migration and to consider these against a background of axonal guidance literature. Although Ephs and ephrins have been implicated in the migration of a range of neuronal and non-neuronal cells (e.g. motor neurons [2], inner ear cells [3], vascular elements [4], Schwann cells and oligodendrocytes $[5,6])$, we will discuss emerging evidence for their role in guiding the migration of newly generated cortical progenitors and neurons [7-11]. In addition, we will discuss the sometimes contradictory evidence suggesting that Eph/ephrins guide migrating neuroblasts along the rostral migratory stream (RMS) to the olfactory bulb in the adult brain $[12,13]$. 


\section{Introduction to Ephs and Ephrins}

Ephrins are membrane-bound proteins which are expressed in many regions of the developing brain. Through their interaction with Eph receptors, they guide cells and their processes to form highly organised brain regions and projections [14, 15]. As versatile signalling molecules, they are involved in many biological processes both during development and in the adult. In addition to their roles in cell proliferation [16], migration [11], neurite extension [17] and branching [18], regeneration [19, 20] and apoptosis [21] in the central nervous system, Ephs and ephrins contribute to vascular development [22-24], embryo implantation [25] and recently have become therapeutic targets in cancer $[26,27]$. Their versatility comes from their regulation of a remarkably wide range of intracellular signalling pathways, resulting in precise and context-dependent regulation of cell-cell interactions [28-30].

Ephrins are divided into A-type components, which are connected to the cell membrane by a glycosylphosphatidylinositol linkage, and B-type components, with a transmembrane sequence [31-33]. Ephrin-Eph receptor binding is mainly type specific although within-type specificity is low; however, between-type interactions have been documented for 2 receptors (EphA4 and EphB2) $[34,35]$. Very early in Eph/ephrin studies, it was suggested that despite this apparent promiscuity, there was the possibility for signalling arising from different combinations of ligands and receptors to result in unique outcomes [33]. Such a specificity may be associated with protein interactions, cell-type-specific or compartmentalised expression of Eph/ephrins, as well as differential recruitment of intracellular signalling pathways [36, 37].

Eph-ephrin signalling is exceptionally powerful because it is bidirectional: through the receptor and the ligand [38]. Eph receptors are receptor tyrosine kinases and after ligand binding, the receptors phosphorylate intracellular proteins that mediate changes in the cytoskeleton, modifying cell shape and movement $[39,40]$. The outcome can be repulsive or attractive for the entire cell (regulating migration) or cellular structure (controlling growth of axons, dendrites or spines) [41,42]. The ephrin ligands also transmit intracellular signals in response to Eph receptor binding: ephrins type B possess a cytoplasmic tail which triggers intracellular signalling via tyrosine phosphorylation sites and a PDZ-binding site [43, 44]. These processes are known as 'reverse signalling' and in some cases are found to have very different outcomes from the 'forward', Eph receptor-mediated signal $[45,46]$. Reverse signalling by ephrins type A is less well charac- terised and is thought to involve membrane-associated Src-related kinases such as Fyn and Src [38, 47]. Interpretation of signals can be further complicated by co-expression of Ephs and ephrins on the same cell, resulting in cis-interactions that have complex modulatory effects on signalling [48-52].

A key aspect of Eph and ephrin signalling is the ability of signals to be either repulsive or attractive depending on the cellular context. Molecular switches have been identified that determine whether responses will be attractive or repulsive: neurotrophins [51, 53], intracellular kinases [7], cAMP [54-56], cytoplasmic structure [57] and expression levels of the Eph/ephrin proteins themselves [17] are all implicated in the signalling outcome. There is also evidence for feedback regulation of Eph and ephrin expression following Eph-ephrin binding in fish and mouse models. In goldfish during optic nerve regeneration, injection of recombinant Eph receptor proteins resulted in altered expression of ephrin ligands in the visual system [19]. Similarly, studies of Eph and ephrin gene expression levels in the cortex of ephrin A5 knockout mice demonstrate upregulation of ephrin A2, EphA5 and EphB within distinct cortical layers [58]. A question raised by these diverse mechanisms is the chronological aspect of the switch between attraction and repulsion. Some mechanisms, such as phosphorylation and proteinprotein interactions are rapid with relatively short halflives, allowing for rapid switching, perhaps in response to transient environmental changes such as neurotransmitter release or growth factor secretion to facilitate plastic changes. By contrast, changes in gene expression would take longer to develop, but have a long-lasting impact on cellular responses to the environment, potentially making significant changes to cell structure and behaviour.

\section{Repulsive Signalling: How and Why?}

The concept of repulsive signalling has been described as paradoxical: Eph-ephrin binding brings cells together - how can they then be separated? A number of mechanisms have been shown to underpin this behaviour. Subsequent to EphA-ephrin-A binding, ephrins A are cleaved by a metalloprotease in hippocampal cells in vitro, allowing ingrowing EphA receptor-expressing axons to retract $[59,60]$. In cortical neurons in vitro, Eph-ephrin binding results in internalisation of the Eph receptor with ephrin still attached $[30,61,62]$. Finally, membrane ripping has been suggested to remove the Eph receptor from the cell surface during migration of cortical cells [7]. 
The concept of repulsive signalling raises another apparent paradox: how can repulsive interactions build a brain with complex circuitry and regionalisation, when attraction would appear to be more useful, particularly in axonal guidance? The advantage of repulsive signalling in cell migration is that it mediates segregation of cell populations [63, 64]. Similarly, repulsive signalling in axon guidance may provide benefits in patterning axonal projections. In a purely attractive environment, connections would form in the first available 'attractive' location, increasing the probability of projection errors as observed in ephrin $A^{-/-}$mice $[65,66]$. The presence of repulsive cues may promote growth cone motility and searching within a target region, allowing other processes such as contributions from other guidance cues or activity-dependent mechanisms to come into play.

\section{Eph-Ephrin Interactions in Cortical Development}

The mammalian neocortex consists of two main neuronal classes, the excitatory glutamatergic pyramidal cells and the inhibitory GABAergic interneurons. The pyramidal cells arise in the cortical proliferative zone (known as the ventricular zone, VZ) of the dorsal telencephalon and migrate radially along the processes of radial glia to form the basic laminar structure of the neocortex [67]. These neurons are the first arrivals in the neocortex and together with Cajal-Retzius cells [68] form a transient structure known as the preplate around embryonic day (E) 10 in mice [1]. The next wave of pyramidal cells splits the preplate into two layers: the superficial marginal zone (layer 1) and a deeper layer, the subplate, forming the cortical plate in between [69]. Subsequently, waves of pyramidal cells enter the cortical plate and form layers that are progressively more superficial as development progresses [70]. At the same time, GABAergic interneurons originating primarily from the $\mathrm{VZ}$ of the subpallium, the medial (MGE) and caudal ganglionic eminences in the basal telencephalon, arrive in the developing cortex by tangential migration (fig. 1). They continue to migrate tangentially within the lower subplate and marginal zone of the cortex, some dive down to the surface of the ventricle, dispersing across the full extent of the cortex. Finally, they adopt a radial migration pattern and enter the cortical plate [71, 72] (fig. 1).

As the pyramidal and interneurons migrate into the developing cortical plate, they establish radially oriented columns based on the distribution of pyramidal cell precursors in the VZ [73] (fig. 1, inset). There is some inter-

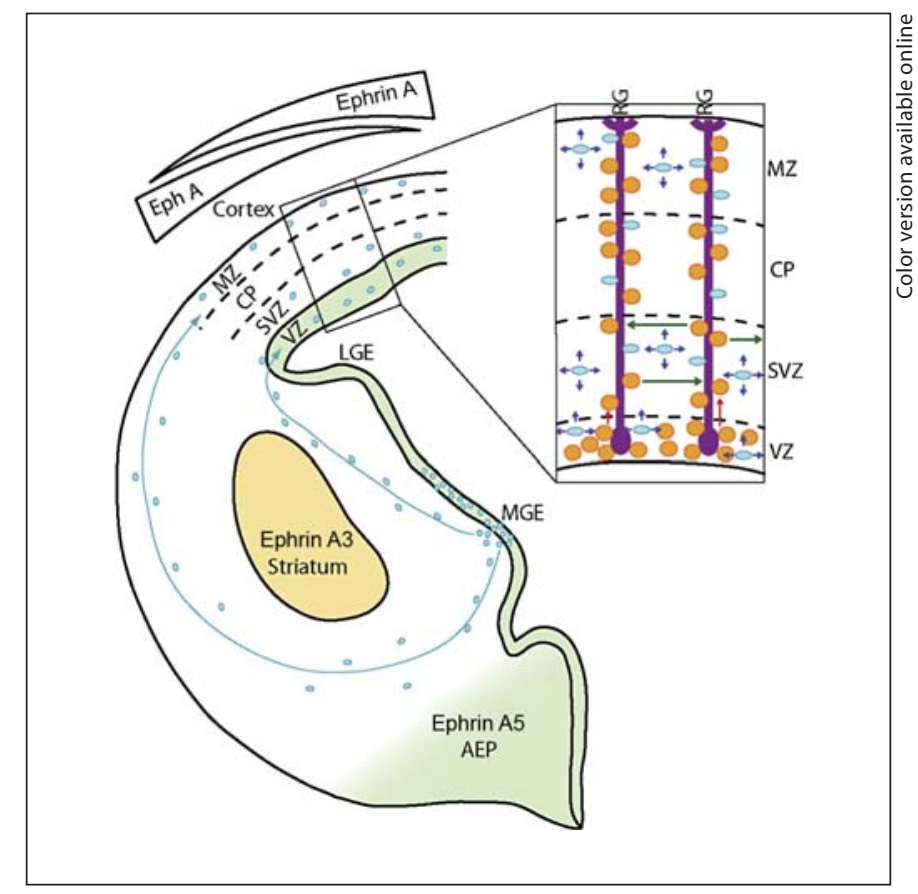

Fig. 1. Migration of cortical neurons during development. Summary of the migration of cortical interneurons (blue; colours in the online version only) and pyramidal projection neurons (orange) into the developing cortex. Interneurons (ovals) express EphA4, are born in the VZ in the MGE and migrate through 'corridors' defined by ephrin A3 (in the striatum) and ephrin A5 (in the $\mathrm{VZ}$ and area entopedunculare, AEP) expression. They enter the cortical plate in the marginal zone, SVZ and VZ and migrate tangentially and radially to attain their final locations in the cortical plate (inset right). Migration of pyramidal (projection) neurons within the cortex is shown in the inset. Developmental gradients of Ephs and ephrins are expressed as shown by wedge shapes above the cortex. Pyramidal neurons (circles) are born within the VZ and migrate (vertical arrows) following the processes of radial glia (RG) using ephrin-B-reelin signalling to form a radially oriented column of clonally related neurons. However, a subset of cells also migrate or 'jump' tangentially (horizontal arrows) between columns, a process mediated by EphA7-ephrinA signalling. The diagram is based on and summarises data from several publications [8-11]. LGE = Lateral ganglionic eminence; $\mathrm{CP}=$ cortical plate; $\mathrm{MZ}=$ marginal zone.

mixing between pyramidal cells from adjacent columns as a subset of these cells undergo a brief tangential migration or lateral 'jump' $[9,74]$. These structures known as microcolumns are highly structured and contain cortical circuits thought to underpin the integration of sensory inputs [75].

Consistent with the widespread and highly regulated expression of Eph receptors and ephrins during cortical development [58, 76-78], there is evidence that ephrins 
are involved in 3 aspects of this complex process: radial migration of pyramidal cells [11], tangential migration of interneurons $[7,8,10]$ and tangential migration of pyramidal cells during formation of microcolumns [9] (fig. 1).

Evidence for ephrins in radial migration comes primarily from studies of the relationship between ephrin B and reelin signalling pathways [11]. Reelin ${ }^{-/}$mice (also known as reeler mice) display a striking phenotype of inverted cortical lamination [67, 79]. Mice with abnormal reelin signalling show disrupted lamination and neuronal morphology in other brain regions including the hippocampus and cerebellum $[70,79,80]$. Reelin is an extracellular matrix protein which exerts its effects by binding to membrane-bound receptors apolipoprotein E/very low-density lipoprotein receptor on neurons [81], resulting in phosphorylation of Dab1 by Src-related kinases [82, 83] and guiding migration, most likely by regulating attachment and detachment from radial glia [79]. However, apolipoprotein E/very low-density lipoprotein receptor does not possess intrinsic kinase activity, requiring a reelin coreceptor molecule to mediate the phosphorylation of Dabl. A recent study has identified ephrins B as coreceptors as they bind directly to reelin and apolipoprotein E/very low-density lipoprotein receptor [11], recruiting Src [84], resulting in phosphorylation of Dab1 [11]. The study used a series of compound mutants that were heterozygous knockout for reelin, but homozygous knockout for one or more ephrin B types. Heterozygous reelin mutants have a normal phenotype, but in combination with an ephrin B knockout, the mice display a typical reelin-like inversion of cortical layers. Furthermore, the ephrin B1/B2/B3 triple knockout mice have a reelin-like phenotype. Spectacular rescue experiments confirmed that the reelin ${ }^{-/}$phenotype could be fully rescued by exogenous clustered EphB-Fc (to activate ephrin B signalling), resulting in appropriate migration to their final destinations of cortical neurons that had accumulated at the ventricular surface [11]. Interestingly, although ephrin $\mathrm{B} 1, \mathrm{~B} 2$ and $\mathrm{B} 3$ all influenced migration of cortical neurons, other brain regions appeared to be more selective for specific family members [11], suggesting that different migration behaviours in these brain regions may recruit different signalling partners to the reelin-ephrin$\mathrm{B}$ complex. The integral role of Src-related kinases in the reelin signalling pathway may also suggest an involvement of ephrins A [47].

In contrast to the role for EphB-ephrin-B signalling in radial migration of pyramidal neurons, tangential migration of inhibitory interneurons has primarily implicated EphA-ephrin-A signalling. The migration of interneu-

Ephs and Ephrins in Neuronal Migration rons is over relatively long distances and is known to rely on a range of short- and long-distance cues including neuregulins, slits and semaphorins [1,85-87], as well as growth factors that initiate and accelerate their migration [88]. A recent addition to this list is EphA4-ephrin-A5 binding, which guides the earliest stages of GABAergic interneuron migration from the MGE into the cortex $[8$, $10]$, but not within the cortex $[9,72]$. Early born interneurons (E12-E13) migrate into the cortex via a deep migration path that runs ventral to the striatum, whereas later born neurons (E13-E17) migrate dorsally to the striatum through the subventricular zone (SVZ) of the telencephalon, running adjacent to the VZ $[10,89,90]$ (fig. 1). Expression patterns of EphA and ephrin A in this system have been clearly described: calbindin-positive interneurons express EphA4 throughout their migration $[8,10]$, whereas ephrin A3 is expressed in the striatum [10] and ephrin A5 in the VZ of the MGE [8], defining the two corridors (ventral and dorsal) that are permissive for the migration of EphA4-positive interneurons (fig. 1). The repulsive action of ephrin A3 and ephrin A5 for EphA4expressing interneurons was confirmed by stripe assays, coculture experiments using siRNA downregulation and blockade of ephrin A ligands with recombinant fusion proteins. The latter experiment additionally provided unexpected information about EphA and ephrin A expression: experiments where wild-type and transgenic brain slices were cocultured to visualise migrating interneurons did not initially show repulsive activity of ephrin A5 in the VZ, due to a downregulation of ephrin A5 in vitro [8]. However, addition of exogenous ephrin-A5-Fc restored the normal migration pattern. The experiments suggest that Eph and ephrin expression is tightly regulated not only cell-intrinsically, but also by environmental cues including circuitry and neuronal firing patterns as suggested by studies of brain injury $[19,20,91,92]$ and plasticity $[93,94]$. Of consequence is the result that when exogenous ephrin-A5-Fc was added to the slice cultures, it bound preferentially to the VZ, suggesting that an Eph receptor may be co-expressed in this location, as described in the visual system [42].

Later stages of neuronal migration in the developing cortex involve the multipolar migration of pyramidal cells $[95,96]$, a process which has recently been shown to involve EphA-ephrin signalling [9] (fig. 1). This study is important because it suggests that Eph-ephrin interactions may be attractive or repulsive in neuronal migration, as they are in axon guidance. Previous studies have illustrated how repulsive interactions define and segregate cell populations, whereas the study by Torii et 


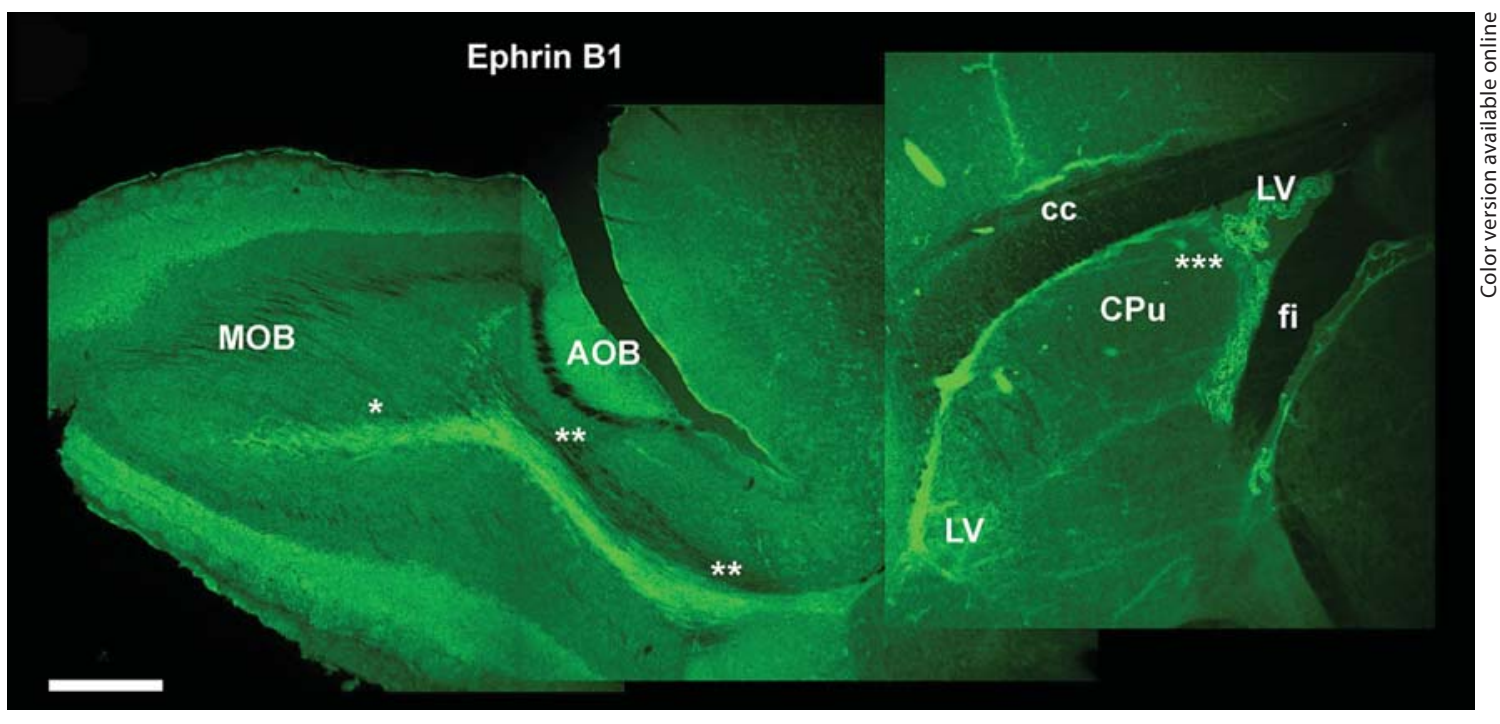

Fig. 2. Ephrin B1 immunoreactivity in SVZ and RMS. Ephrin B1 expression in adult mouse brain longitudinal sections including the SVZ and RMS pathway. The panel is a photomontage of $2 \mathrm{sec}-$ tions: one cut longitudinally at $1.3 \mathrm{~mm}$ from the midline (left, centre) and the other cut at $1.7 \mathrm{~mm}$ from the midline (right). Immunoreactivity is detected in the SVZ beneath the lateral ventricle (LV), which is displayed at the anterior and posterior aspects of the striatum/caudoputamen $(\mathrm{CPu})$, under the corpus callosum (cc) and in front of the fimbria (fi), respectively $\left({ }^{* *}\right)$. Immunore-

al. [9] demonstrates Eph-ephrin-mediated cell dispersion, a process that may involve attraction. The study shows that ephrin A2/A3/A5 triple knockout mice have significant disruption of cell organisation in the tangential but not radial orientation, with areas of highly irregular neuronal distributions within layers. Although the authors definitively show that EphA7-ephrin-A interactions are important for regulating this tangential dispersion, it remains unclear why areas of abnormal lamination are patchy and apparently randomly distributed throughout the cortex in ephrin triple knockout mice. Possibilities include that these proteins may contribute to cortical arealisation in ways that remain to be determined. It is interesting to note that the individual variation in cortical laminar disruption in ephrin triple knockout mice is reminiscent of the defects in axon guidance in the visual system of ephrin A single, double and triple knockout mice, which are detected in only a proportion of animals and affect only some cells $[65,66$, 97-99]. This individual variation may reflect the inherent ability of Eph-ephrin signalling to integrate with other molecular cues, as well as with activity-dependent mechanisms $[30,100]$. activity is also detected in the main section of the RMS, at the entrance and along the olfactory peduncle $\left(^{* *}\right)$ and within the olfactory bulb $(*)$. MOB = Main olfactory bulb; $\mathrm{AOB}=$ accessory olfactory bulb. Methods for ephrin B1 immunohistochemistry are as described in Migani et al. [78], and additional details are provided in the supplementary material (for all online suppl. material, see www.karger.com/doi/10.1159/000333784). Scale bar $=400$ $\mu \mathrm{m}$.

\section{Eph-Ephrin Interactions in the Migration of Neuroblasts along the RMS}

In the adult rodent brain, neurogenesis takes place primarily in two zones: the SVZ, which lies below the medioventral striatal surface of the lateral ventricle, and the subgranular zone of the hippocampal fascia dentata [101]. Neuroblasts produced in the SVZ migrate along the RMS to their final destination in the olfactory bulb where they differentiate and integrate into the bulb layers [102] (fig. 2). The cells remain strictly within the RMS for the duration of this long migration, suggesting that powerful mechanisms are at work to define the boundaries of the migration path.

In the SVZ, neuroblasts (A cells) originate in cell clusters under the ventricular epithelium. Each cluster is wrapped by glial-type cells (B cells), which are the principal self-generating (stem) cells. The B cells also generate neuroblasts and rapidly dividing $C$ cells, which amplify the production of neuroblasts $[103,104]$. Neuroblasts migrate out of the SVZ in chains which are aligned mainly in the rostrocaudal direction under the ventricular epithelium, at the surface of the corpus striatum. These 
chains converge at the anterior angle of the ventricle and form the RMS, a compact single pathway which enters the core of the olfactory bulb (fig. 2) [105-107]. In addition to neuroblasts, the RMS also contains a dense meshwork of astroglial cells forming long tube-like structures, which contain and presumably guide the migrating cells [108]. Self-generating cells may also be present in the RMS [109] but their ability to produce neuroblasts in this location has not been assessed. When neuroblasts reach the central part of the olfactory bulb, they make a final radial turn and develop into olfactory granule and periglomerular cells, which integrate into primary olfactory circuits as interneurons $[110,111]$.

Several studies have identified factors which guide neuroblasts along their SVZ-RMS path, but the process remains poorly understood. The vasculature has been suggested to provide structural guidance, both at the level of individual cells migrating into the olfactory bulb [112] and for the bulk of neuroblasts along the RMS [113, 114]. Alternatively, neuroblasts may be self-guided, associating into chains along the RMS via homophilic mechanisms whereby cells follow signals generated by cells of the same type [115]. However, a key requirement for guidance along the RMS is the presence of repelling factors in the tissue surrounding the path, as well as the expression of factors with attracting power in the final target area [113]. Possible candidates for these roles are extracellular matrix components $[112,116,117]$ and soluble or membrane-bound factors with chemorepulsive or chemo-attractive effects [118-121].

Our work and that of others has implicated EphB-ephrin- $B$ interactions in regulating neurogenesis within the SVZ and in guiding neuroblast migration. The clearest evidence for a role for EphB-ephrin-B interactions comes from a study which infused recombinant EphB2 and ephrin $\mathrm{B} 2$ fusion proteins into the SVZ of adult mice, and showed disrupted migration and proliferation of neural stem cells in the SVZ. Subsequent studies have confirmed the role of EphB-ephrin-B interactions in regulating cell proliferation within the SVZ [122] (ephrin B3 specifically [13]), but also raise doubts about the identity of which ephrins type B are involved, as well as the type of cells in which they are expressed [78], making it difficult to determine mechanisms of action. In situ hybridisation and LacZ constructs have shown that EphB1 and EphB2 are expressed in cells of the SVZ surrounding chains of migrating neuroblasts, although the specific cell type (astrocytes, $\mathrm{C}$ cell or ependymal cell) could not be resolved [12]. The same study used combinations of recombinant fusion proteins $(-\mathrm{Fc})$ and PCR to detect ephrin B2 and B3, but not ephrin B1, in astrocytes in the SVZ [12]. A later study detected ephrin B1 and B2 but not ephrin B3 in the SVZ by immunohistochemistry and confirmed colocalisation of these proteins with glial fibrillary acidic protein (GFAP) [13]. In addition, our previous work confirmed strong immunoreactivity for ephrin B1 in the RMS region of the olfactory bulb in the mouse [78]. We sought to further investigate ephrin B1 expression in the RMS, and our recent unpublished results (fig. 2, 3) suggest that although a proportion of ephrin-B1-positive cells also express GFAP (fig. 3c, g) in the SVZ and RMS, consistent with previous studies in the SVZ $[12,13]$, a significant number are GFAP negative and are rather double labelled with polysialylated neural cell adhesion molecule-neural cell adhesion molecule and doublecortin (DCX), both markers for migrating neuroblasts (A cells; fig. 3a, b, e, f). The chains of ephrin-B1-positive cells also aligned with blood vessels in the RMS (fig. 3d), consistent with the vasculature contributing to guidance of neuroblasts along this pathway [112-114].

Despite some contradictions in the literature, there is therefore strong evidence that ephrins type B contribute to guiding neuroblasts from their production site in the SVZ to their destination in the olfactory bulb. Moreover, possible expression of ephrin B1 on migrating elements instead of on surrounding tissues and glia would imply that the guidance mechanism involves receptor-like ('reverse') signalling in these cells. A guidance mechanism of this kind is involved in the formation of the corpus callosum, where ephrin-B1-expressing immature cortical axons are forced to cross the midline by the repulsive effect of the EphB2 receptor in the surrounding septal and subcortical tissues; the intracellular signalling within cortical axons is mediated by the PDZ-binding domain on ephrin B1 [123]. Another mechanism which could be triggered by ephrin $\mathrm{B} 1$ on neuroblasts is migration by attraction to (or less likely by repulsion from) an Eph receptor expressed on neighbouring cells. A mechanism of this type fits the model of homophilic guidance and implies the existence of subpopulations of ephrin B and EphB receptor-bearing neuroblasts. A possible specialization among neuroblasts is suggested by our data, since we observed two separate populations of neuroblasts: one that was ephrin B1 immunopositive (double-labelled) and the other ephrin B1 immunonegative (single-labelled; fig. 3). Furthermore, a spatial dimension to the separate populations was highlighted by DCX labelling, which revealed that the proportion of double-labelled cells progressively decreased from the SVZ to the olfactory bulb (fig. 3). A possibility is that the ephrin B1 single-labelled cells we 


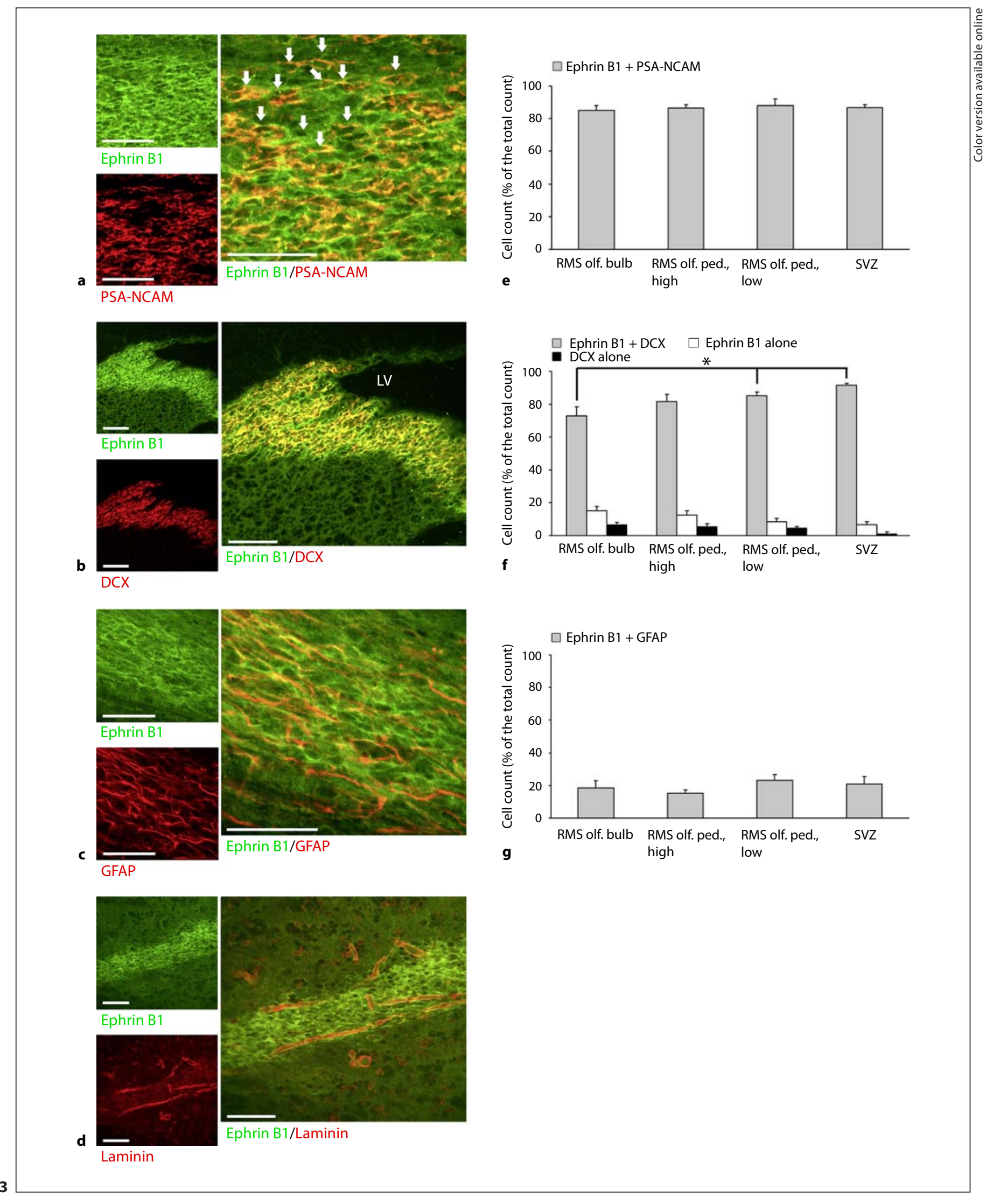


detect could correspond to the DCX-negative neuroblasts previously identified in the SVZ-RMS pathway [124]. The presence of two separate populations could represent the selective loss of ephrin B1 or DCX expression by maturing and differentiating neuroblasts.

Confirmation of the ephrin-B1-dependent guidance mechanisms proposed above requires more information about the expression of B-type Eph receptors in the tissue surrounding the SVZ and the RMS path, as well as on migrating neuroblasts themselves. An online database of specific mRNA distribution (Allen Brain Atlas) has shown that, of the Eph receptors that have been shown to bind ephrin B1, EphA4, EphB1 and EphB2 mRNAs are transcribed in the anterior forebrain and olfactory tissue, however, no signal above background is detected in the SVZ-RMS path. These data contrast with previous studies showing strong EphB2, EphB3 and EphA4 expression in the SVZ in adult mice [12]. Although contradictory, these data suggest that ephrin B1 guidance of neuroblast migration may be independent of EphB receptors. The possibility is consistent with experiments showing that ventricular injection of ephrin B1 ectodomain failed to disturb the formation of neuroblast chains, whereas a similar treatment with ephrin B2 and EphB2 ectodomains produced striking effects [12]. A possible explanation is that the mechanism relies on ephrin $\mathrm{B} 2$ binding to EphA4 [33, 34], a mechanism which would not be acti-

Fig. 3. Colocalisation of ephrin B1 with neuroblasts and glial cells in the RMS and SVZ. a Ephrin B1/polysialylated neural cell adhesion molecule-neural cell adhesion molecule (PSA-NCAM) immunoreactivity in the medial part of the RMS. Double-labelled profiles are indicated by arrows. $\mathbf{b}$ Clusters of cells in posterior positions of the SVZ, showing extensive colocalisation of ephrin B1 and DCX immunoreactivity. c Distribution of ephrin B1 and GFAP immunoreactivity in the SVZ and RMS. d Chains of ephrin-B1-labelled cellular profiles following the direction of laminin-positive blood vessels in the medial region of the RMS. All scale bars $=50 \mu \mathrm{m}$. Histograms show the percentage of ephrin B1 and neuroblast or glial marker double-labelled cells in RMS and SVZ. Bars represent the percentage of double-labelled cells in the RMS at the olfactory (olf.) bulb level (* in fig. 2), at two levels in the olfactory peduncle (ped.; ${ }^{* *}$ in fig. 2 ), and in the SVZ (*** in fig. 2). Data are presented as mean values \pm standard error. Significant differences (ANOVA, $\mathrm{p}<0.05$ ) were observed only for ephrin B1 + DCX, ephrin B1 alone and DCX alone data sets. Post hoc analysis (Student-Newman-Keuls test) revealed significant $(\mathrm{p}<0.05)$ differences indicated by the asterisk. Methods for ephrin B1 immunohistochemistry are as described in Migani et al. [78], and additional details of antibodies and analysis are provided as online supplementary material.

Ephs and Ephrins in Neuronal Migration vated by ephrin B1 which binds only weakly to EphA4 $[40,125]$. Alternatively, EphB and ephrin B may control cell migration via two distinct mechanisms, one that is Eph receptor dependent (via ephrin B2) and the other that is Eph receptor independent via ephrin B1. It has previously been shown that ephrin B1 phosphorylation can be induced by activation of the platelet-derived growth factor receptor [126]. Furthermore other neurotrophic factor receptors, already shown to be involved in neuroblast production and guidance $[113,121,127]$, may similarly crosstalk with ephrin B1 signalling as they do for EphAs and ephrins type A $[51,53]$. Possible candidates for this role are the intracellular protein Ankyrin Repeat rich Membrane Spanning (ARMS) [128] although its expression in the SVZ/RMS is not described, the p75 neurotrophin receptor, which is expressed in RMS neuroblasts [113], or the tropomyosin receptor kinase (TrkB) receptor, although its expression on RMS neuroblasts is more controversial $[113,121]$. The possibility of interaction between ephrin B1 and TrkB at the same cellular site is suggested by the inhibitory effect of ephrin $\mathrm{B} 1$ on the mitotic activity of TrkB/brain-derived neurotrophic factor-transfected cells [126]. Furthermore, there is evidence in the RMS-SVZ system that TrkB receptor on glial cells regulates brain-derived neurotrophic factor availability for the p75 neurotrophin receptor on neuroblasts [113]. Future studies of neurotrophic factor receptors and Eph tyrosine kinase receptor expression in this system are required to elucidate the mechanism of Eph/ephrin-mediated neuroblast guidance.

\section{Should I Stay or Should I Go? Parallels between Axon Guidance and Migration}

In conclusion, Eph-ephrin signalling pathways in axon guidance and neuronal migration have much in common through their shared molecular components and cellular effects $[7,28]$. However, these similarities raise a problem: how does the cell know whether to respond to a cue with just a growth cone response, or by a whole cell movement? For example, as discussed above, in the developing mammalian cortex, ephrins type A do not regulate radial positioning in projection neurons, this is accomplished by ephrins B [11], but ephrins A do regulate axon and dendritic targeting and connectivity of these same projection neurons [98, 99, 129-131]. The large number of possible combinations of Ephs and ephrins in vertebrates makes linking individual signalling events to cellular responses (such as axon guidance or 
migration) challenging. Furthermore, the difficulties inherent in identifying the different Eph and ephrin family members, particularly in the absence of reliable and specific antibodies to many of the individual proteins, result in contradictions within the field. Thus, early stages of these important experiments may be optimally accomplished in single Eph-ephrin pair models, such as those of some insects. Manduca sexta (the tobacco hornworm) and Drosophila melanogaster provide a much simpler environment in which to study Ephs and ephrins because a single family member is present for each; the insect ephrin is a glycosylphosphatidylinositol-linked protein similar to vertebrate ephrins A. Most studies show a role for these proteins in axon guidance: in both insects, Ephephrin signaling has primarily been implicated in axon guidance related to the processing of olfactory cues. In Drosophila the proteins are involved in axon guidance within the mushroom body, a structure implicated in learning memory, particularly for chemical (odorant) stimuli [132], while in Manduca, Eph and ephrin may play a similar role in sorting olfactory sensory axons within the antenna [133]. Evidence for Eph-ephrin sig- naling in neuronal migration comes primarily from larval Manduca, in which these proteins restrict the migration of neurons, keeping cells aligned within the railroadlike nervous system of the larval insect [134]. Reverse signalling via ephrin has also been suggested to prevent midline crossing and reduce motility, similar to effects seen in vertebrate brains [135]. Thus, invertebrate Ephephrin signalling mediates a similar range of cell behaviours as do their vertebrate counterparts, but does so with a restricted palette that may facilitate elucidation of the intracellular pathways and switches that determine which behaviours are elicited. This fundamental biological understanding would provide the foundations for more targeted interventions in health and disease.

\section{Acknowledgements}

J.R. is an NHMRC Senior Research Fellow. The authors would like to thank Simone Bellagamba (UNIVPM ) and Marissa Penrose (UWA) for assistance with image and text processing and Tenelle Wilks for critical reading of the manuscript.

\section{References}

1 Marin O, Valiente M, Ge X, Tsai LH: Guiding neuronal cell migrations. Cold Spring Harb Perspect Biol 2010;2:a001834.

$\checkmark 2$ Drescher U: Axon guidance: push and pull with ephrins and GDNF. Curr Biol 2011; 21:R30-R32.

-3 Saeger BM, Suhm M, Neubuser A: Ephrin/ ephrin receptor expression during early stages of mouse inner ear development. Dev Dyn 2011;240:1578-1585.

4 Zhou N, Zhao WD, Liu DX, Liang Y, Fang WG, Li B, Chen YH: Inactivation of EphA2 promotes tight junction formation and impairs angiogenesis in brain endothelial cells. Microvasc Res 2011;82:113-121.

5 Wilby MJ, Muir EM, Fok-Seang J, Gour BJ, Blaschuk OW, Fawcett JW: N-cadherin inhibits Schwann cell migration on astrocytes. Mol Cell Neurosci 1999;14:66-84.

-6 Prestoz L, Chatzopoulou E, Lemkine G, Spassky N, Lebras B, Kagawa T, Ikenaka K, Zalc B, Thomas JL: Control of axonophilic migration of oligodendrocyte precursor cells by Eph-ephrin interaction. Neuron Glia Biol 2004;1:73-83.

7 Zimmer G, Kastner B, Weth F, Bolz J: Multiple effects of ephrin-A5 on cortical neurons are mediated by SRC family kinases. J Neurosci 2007;27:5643-5653.
8 Zimmer G, Garcez P, Rudolph J, Niehage R, 14 Coulthard M, Duffy S, Down M, Evans B, Weth F, Lent R, Bolz J: Ephrin-A5 acts as a repulsive cue for migrating cortical interneurons. Eur J Neurosci 2008;28:62-73.

9 Torii M, Hashimoto-Torii K, Levitt P, Rakic $P$ : Integration of neuronal clones in the radial cortical columns by EphA and ephrin-A signalling. Nature 2009;461:524-528.

10 Rudolph J, Zimmer G, Steinecke A, Barchmann S, Bolz J: Ephrins guide migrating cortical interneurons in the basal telencephalon. Cell Adh Migr 2010;4:400-408.

11 Senturk A, Pfennig S, Weiss A, Burk K, Acker-Palmer A: Ephrin Bs are essential components of the Reelin pathway to regulate neuronal migration. Nature 2011;472:356-360.

12 Conover JC, Doetsch F, Garcia-Verdugo J-M, Gale NW, Yancopoulos GD, Alvarez-Buylla A: Disruption of Eph/ephrin signaling affects migration and proliferation in the adult subventricular zone. Nat Neurosci 2000;3: 1091-1097.

13 Ricard J, Salinas J, Garcia L, Liebl DJ: EphrinB3 regulates cell proliferation and survival in adult neurogenesis. Mol Cell Neurosci 2006;31:713-722. Power M, Smith F, Stylianou C, Kleikamp S, Oates A, Lackmann M, Burns G, Boyd A: The role of the Eph-ephrin signalling system in the regulation of developmental patterning. Int J Dev Biol 2002;46:375-384.

15 Palmer A, Klein R: Multiple roles of ephrins in morphogenesis, neuronal networking, and brain function. Genes Dev 2003;17: 1429-1450.

16 Jiao JW, Feldheim DA, Chen DF: Ephrins as negative regulators of adult neurogenesis in diverse regions of the central nervous system. Proc Natl Acad Sci USA 2008; 105:8778-8783.

17 Hansen MJ, Dallal GE, Flanagan JG: Retinal axon response to ephrin-As shows a graded, concentration-dependent transition from growth promotion to inhibition. Neuron 2004;42:717-730.

18 Yates PA, Roskies AL, McLaughlin T, O'Leary DDM: Topographic-specific axon branching controlled by ephrin-As is the critical event in retinotectal map development. J Neurosci 2001;21:8548-8563.

19 Rodger J, Vitale PN, Tee LB, King CE, Bartlett CA, Fall A, Brennan C, O'Shea JE, Dunlop SA, Beazley LD: EphA/ephrin-A interactions during optic nerve regeneration: restoration of topography and regulation of ephrin-A2 expression. Mol Cell Neurosci 2004;25:56-68. 
20 Goldshmit Y, McLenachan S, Turnley A: Roles of Eph receptors and ephrins in the normal and damaged adult CNS. Brain Res Rev 2006;52:327-345.

-21 Depaepe V, Suarez-Gonzalez N, Dufour A, Passante L, Gorski JA, Jones KR, Ledent C, Vanderhaeghen P: Ephrin signalling controls brain size by regulating apoptosis of neural progenitors. Nature 2005;435:12441250.

22 Daniel TO, Stein E, Cerretti DP, St John PL, Robert B, Abrahamson DR: ELK and LERK2 in developing kidney and microvascular endothelial assembly. Kidney Int Suppl 1996; 57:S73-S81.

-23 Wang HU, Chen ZF, Anderson DJ: Molecular distinction and angiogenic interaction between embryonic arteries and veins revealed by ephrin-B2 and its receptor Eph-B4 . Cell 1998;93:741-753.

24 Goldshmit Y, Galea MP, Bartlett PF, Turnley AM: EphA4 regulates central nervous system vascular formation. J Comp Neurol 2006;497:864-875.

-25 Fujii H, Fujiwara H, Horie A, Sato Y, Konishi I: Ephrin A1 induces intercellular dissociation in Ishikawa cells: possible implication of the Eph-ephrin A system in human embryo implantation. Hum Reprod 2011;26:299306.

26 Herath NI, Boyd AW: The role of Eph receptors and ephrin ligands in colorectal cancer. Int J Cancer 2010;126:2003-2011.

-27 Mitra S, Duggineni S, Koolpe M, Zhu X, Huang Z, Pasquale EB: Structure-activity relationship analysis of peptides targeting the EphA2 receptor. Biochemistry 2010;49: 6687-6695.

28 Mellitzer G, Xu G, Wilkinson D: Control of cell behaviour by signalling through Eph receptors and ephrins. Curr Opin Cell Biol 2000;10:400-408.

29 Lackmann M, Boyd AW: Eph, a protein family coming of age: more confusion, insight, or complexity? Sci Signal 2008; 1:re2.

-30 Pitulescu ME, Adams RH: Eph/ephrin molecules - a hub for signaling and endocytosis. Genes Dev 2010;24:2480-2492.

31 Committee EN: Unified nomenclature for Eph family receptors and their ligands, the ephrins. Eph Nomenclature Committee. Cell 1997;90:403-404.

-32 Lemke G: A coherent nomenclature for Eph receptors and their ligands. Mol Cell Neurosci 1997;9:331-332.

-33 Wilkinson DG: Multiple roles of Eph receptors and ephrins in neural development. Nat Rev Neurosci 2001;2:155-164.

-34 Himanen JP, Chumley MJ, Lackmann M, Li C, Barton WA, Jeffrey PD, Vearing C, Geleick D, Feldheim DA, Boyd AW, Henkemeyer M, Nikolov DB: Repelling class discrimination: ephrin-A5 binds to and activates EphB2 receptor signaling. Nat Neurosci 2004;7:501509.
Pasquale EB: Eph-ephrin promiscuity is now crystal clear. Nat Neurosci 2004;7:417-418.

-36 Stein E, Lane AA, CerrettiDP, Schoecklmann HO, Schroff AD, Van Etten RL, Daniel TO: Eph receptors discriminate specific ligand oligomers to determine alternative signaling complexes, attachment, and assembly responses. Genes Dev 1998;12:667-678.

37 Poopalasundaram S, Marler KJ, Drescher U: EphrinA6 on chick retinal axons is a key component for p75(NTR)-dependent axon repulsion and TrkB-dependent axon branching. Mol Cell Neurosci 2011;47:131-136.

38 Davy A, Soriano P: Ephrin signaling in vivo: look both ways. Dev Dyn 2005;232:1-10.

39 Poliakov A, Cotrina M, Wilkinson DG: Diverse roles of Eph receptors and ephrins in the regulation of cell migration and tissue assembly. Dev Cell 2004;7:465-480.

40 Himanen JP, Saha N, Nikolov DB: Cell-cell signaling via Eph receptors and ephrins. Curr Opin Cell Biol 2007;19:534-542.

-41 Santiago A, Erickson CA: Ephrin-B ligands play a dual role in the control of neural crest cell migration. Development 2002;129:36213632.

42 McLaughlin T, O’Leary DD: Molecular gradients and development of retinotopic maps. Annu Rev Neurosci 2005;28:327-355.

43 Lin D, Gish GD, Songyang Z, Pawson T: The carboxyl terminus of $\mathrm{B}$ class ephrins constitutes a PDZ domain binding motif. J Biol Chem 1999;274:3726-3733.

44 Cowan CA, Henkemeyer M: The SH2/SH3 adaptor Grb4 transduces B-ephrin reverse signals. Nature 2001;413:174-179.

45 Murai KK, Pasquale EB: 'Eph'ective signaling: forward, reverse and crosstalk. J Cell Sci 2003;116:2823-2832.

46 Pasquale EB: Eph-ephrin bidirectional signaling in physiology and disease. Cell 2008; 133:38-52.

47 Davy A, Gale NW, Murray EW, Klinghoffer RA, Soriano P, Feuerstein C, Robbins SM: Compartmentalised signaling by GPI-anchored ephrin-A5 requires the Fyn tyrosine kinase to regulate cellular adhesion. Genes Dev 1999;13:3125-3135.

48 Hornberger M, Dutting D, Ciossek T, Yamada T, Handwerker C, Lang S, Weth F, Huf J, Wessel R, Logan C, Tanaka H, Drescher U: Modulation of EphA receptor function by coexpressed ephrinA ligands on retinal ganglion cell axons. Neuron 1999;22:731-742.

49 Sobieszczuk DF, Wilkinson DG: Masking of Eph receptors and ephrins. Curr Biol 1999; 9:R469-R470.

50 Marquardt T, Shirasaki R, Ghosh S, Andrews SE, Carter N, Hunter T, Pfaff SL: Coexpressed EphA receptors and ephrin-A ligands mediate opposing actions on growth cone navigation from distinct membrane domains. Cell 2005;121:127-139.
51 Marler KJ, Becker-Barroso E, Martinez A, Llovera M, Wentzel C, Poopalasundaram S, Hindges R, Soriano E, Comella J, Drescher $\mathrm{U}: \mathrm{A}$ TrkB/Ephrin A interaction controls retinal axon branching and synaptogenesis. J Neurosci 2008;28:12700-12712.

52 Kao TJ, Kania A: Ephrin-mediated cis-attenuation of Eph receptor signaling is essential for spinal motor axon guidance. Neuron 2011;71:76-91.

53 Fitzgerald M, Buckley A, Lukehurst SS, Dunlop SA, Beazley LD, Rodger J: Neurite responses to ephrin-A5 modulated by BDNF: evidence for TrkB-EphA interactions. Biochem Biophys Res Commun 2008;374:625630.

54 Rodger J, Goto H, Cui Q, Chen PB, Harvey AR: cAMP regulates axon outgrowth and guidance during optic nerve regeneration in goldfish. Mol Cell Neurosci 2005;30:452464.

-55 Nicol X, Muzerelle A, Rio J, Metin C, Gaspar P: Requirement of Adenylate Cyclase 1 for the ephrin-A5-dependent retraction of exuberant retinal axons. J Neurosci 2006;26: 862-872.

56 Nicol X, Voyatzis S, Muzerelle A, NarbouxNeme N, Sudhof T, Miles R, Gaspar P: cAMP oscillations and retinal activity are permissive for ephrin signalling during the establishment of the retinotopic map. Nat Neurosci 2007;10:340-347.

57 Truitt L, Freywald A: Dancing with the dead: Eph receptors and their kinase-null partners. Biochem Cell Biol 2011;89:115-129.

58 Peuckert C, Wacker E, Rapus J, Levitt P, Bolz $\mathrm{J}$ : Adaptive changes in gene expression patterns in the somatosensory cortex after deletion of ephrinA5. Mol Cell Neurosci 2008; 39:21-31.

59 Hattori M, Osterfield M, Flanagan JG: Regulated cleavage of a contact-mediated axon repellent. Science 2000;289:1360-1364.

60 Janes PW, Saha N, Barton WA, Kolev MV, Wimmer-Kleikamp SH, Nievergall E, Blobel CP, Himanen JP, Lackmann M, Nikolov DB: Adam meets Eph: an ADAM substrate recognition module acts as a molecular switch for ephrin cleavage in trans. Cell 2005;123: 291-304.

61 Marston D, Dickinson S, Nobes C: Rac-dependent trans-endocytosis of ephrinBs regulates Eph-ephrin contact repulsion. Nat Cell Biol 2003;5:879-888.

-62 Zimmer M, Palmer A, Kohler J, Klein R: EphB-ephrinB bi-directional endocytosis terminates adhesion allowing contact mediated repulsion. Nat Cell Biol 2003;5:869-878.

63 Mellitzer G, Xu Q, Wilkinson DG: Eph receptors and ephrins restrict cell intermingling and communication. Nature 1999;400: 77-80.

64 Honda H, Mochizuki A: Formation and maintenance of distinctive cell patterns by coexpression of membrane-bound ligands and their receptors. Dev Dyn 2002;223:180192. 
-65 Feldheim DA, Kim Y-I, Bergemann AD, Frisen J, Barbacid M, Flanagan JG: Genetic analysis of ephrin-A2 and ephrin-A5 shows their requirement in multiple aspects of retinocollicular mapping. Neuron 2000;25:563574.

-66 Haustead D, Lukehurst S, Clutton GB, Bartlett CA, Dunlop S, Arrese CA, Sherrard RM, Rodger J: Functional topography and integration of the contralateral and ipsilateral retinocollicular projections in ephrin$\mathrm{A}^{-1-}$ mice. J Neurosci 2008;28:7376-7386.

67 Rakic P, Caviness VS Jr: Cortical development: view from neurological mutants two decades later. Neuron 1995;14:1101-1104.

- 68 Bielle F, Griveau A, Narboux-Neme N, Vigneau S, Sigrist M, Arber S, Wassef M, Pierani A: Multiple origins of Cajal-Retzius cells at the borders of the developing pallium. Nat Neurosci 2005;8:1002-1012.

-69 Angevine JB Jr, Sidman RL: Autoradiographic study of cell migration during histogenesis of cerebral cortex in the mouse. Nature 1961;192:766-768.

-70 Bielas S, Higginbotham H, Koizumi H, Tanaka T, Gleeson JG: Cortical neuronal migration mutants suggest separate but intersecting pathways. Annu Rev Cell Dev Biol 2004;20:593-618.

-71 Ang ES Jr, Haydar TF, Gluncic V, Rakic P: Four-dimensional migratory coordinates of GABAergic interneurons in the developing mouse cortex. J Neurosci 2003;23:58055815.

-72 Tanaka D, Nakaya Y, Yanagawa Y, Obata K, Murakami F: Multimodal tangential migration of neocortical GABAergic neurons independent of GPI-anchored proteins. Development 2003;130:5803-5813.

-73 Mountcastle VB: The columnar organization of the neocortex. Brain 1997;120:701722.

-74 Yu YC, Bultje RS, Wang X, Shi SH: Specific synapses develop preferentially among sister excitatory neurons in the neocortex. Nature 2009;458:501-504.

75 Buxhoeveden DP, Casanova MF: The minicolumn hypothesis in neuroscience. Brain 2002;125:935-951.

-76 Yun ME, Johnson RR, Antic A, Donoghue MJ: EphA family gene expression in the developing mouse neocortex: regional patterns reveal intrinsic programs and extrinsic influence. J Comp Neurol 2003;456:203-216.

-77 Migani P, Bartlett C, Dunlop S, Beazley L, Rodger J: Ephrin-B2 immunoreactivity distribution in adult mouse brain. Brain Res 2007;1182:60-72.

78 Migani P, Bartlett C, Dunlop S, Beazley L, Rodger J: Regional and cellular distribution of ephrin-B1 in adult mouse brain. Brain Res 2009;1247:50-61.

-79 Tissir F, Goffinet AM: Reelin and brain development. Nat Rev Neurosci 2003;4:496505.
80 Gallagher E, Howell BW, Soriano P, Cooper JA, Hawkes R: Cerebellar abnormalities in the disabled (mdab1-1) mouse. J Comp Neurol 1998;402:238-251.

81 Trommsdorff M, Gotthardt M, Hiesberger T, Shelton J, Stockinger W, Nimpf J, Hammer RE, Richardson JA, Herz J: Reeler/disabledlike disruption of neuronal migration in knockout mice lacking the VLDL receptor and ApoE receptor 2. Cell 1999;97:689-701.

82 Arnaud L, Ballif BA, Forster E, Cooper JA: Fyn tyrosine kinase is a critical regulator of disabled-1 during brain development. Curr Biol 2003;13:9-17.

83 Bock HH, Herz J: Reelin activates SRC family tyrosine kinases in neurons. Curr Biol 2003;13:18-26.

84 Palmer A, Zimmer M, Erdmann KS, Eulenburg V, Porthin A, Heumann R, Deutsch U, Klein R: EphrinB phosphorylation and reverse signaling: regulation by Src kinases and PTP-BL phosphatase. Mol Cell 2002;9: 725-737.

-85 Marin O, Yaron A, Bagri A, Tessier-Lavigne M, Rubenstein JL: Sorting of striatal and cortical interneurons regulated by semaphorinneuropilin interactions. Science 2001;293: 872-875.

86 Flames N, Long JE, Garratt AN, Fischer TM, Gassmann M, Birchmeier C, Lai C, Rubenstein JL, Marin O: Short- and long-range attraction of cortical GABAergic interneurons by neuregulin-1. Neuron 2004;44:251-261.

-87 Andrews W, Barber M, Hernadez-Miranda LR, Xian J, Rakic S, Sundaresan V, Rabbitts TH, Pannell R, Rabbitts P, Thompson H, Erskine L, Murakami F, Parnavelas JG: The role of Slit-Robo signaling in the generation, migration and morphological differentiation of cortical interneurons. Dev Biol 2008; 313:648-658.

88 Powell EM, Mars WM, Levitt P: Hepatocyte growth factor/scatter factor is a motogen for interneurons migrating from the ventral to dorsal telencephalon. Neuron 2001;30:7989.

89 Marin O, Rubenstein JL: A long, remarkable journey: tangential migration in the telencephalon. Nat Rev Neurosci 2001;2:780-790.

90 Marin O, Rubenstein JL: Cell migration in the forebrain. Annu Rev Neurosci 2003;26: 441-483.

91 Rodger J, Bartlett CA, Beazley LD, Dunlop SA: Transient up-regulation of the rostrocaudal gradient of ephrin A2 in the tectum coincides with re-establishment of orderly projections during optic nerve regeneration in goldfish. Exp Neurol 2000;166:196-200.

92 Rodger J, Lindsay KA, Leaver SG, King CE, Dunlop SA, Beazley LD: Expression of ephrin-A2 in the superior colliculus and EphA5 in the retina following optic nerve section in adult rat. Eur J Neurosci 2001; 14:1929-1936.
$\$ 93$ Gerlai R, Shinsky N, Shih A, Williams P, Winer J, Armanini M, Cairns B, Winslow J, Gao W-Q, Philips HS: Regulation of learning by EphA receptors: a protein targeting study. J Neurosci 1999;19:9538-9549.

94 Bahi A, Dreyer JL: Cocaine-induced expression changes of axon guidance molecules in the adult rat brain. Mol Cell Neurosci 2005;28:275-291.

-95 Tabata H, Nakajima K: Multipolar migration: the third mode of radial neuronal migration in the developing cerebral cortex. J Neurosci 2003;23:9996-10001.

96 Britanova O, Alifragis P, Junek S, Jones K, Gruss P, Tarabykin V: A novel mode of tangential migration of cortical projection neurons. Dev Biol 2006;298:299-311.

$\checkmark 97$ Pfeiffenberger C, Yamada J, Feldheim DA: Ephrin-As and patterned retinal activity act together in the development of topographic maps in the primary visual system. J Neurosci 2006;26:12873-12884.

-98 Cang J, Niell C, Liu X, Pfeiffenberger C, Feldheim D, Stryker M: Selective disruption of one cartesian axis of cortical maps and receptive fields by deficiency in ephrinAs and structured activity. Neuron 2008; 57:511-523.

99 Wilks T, Rodger J, Harvey AR: A role for ephrin-As in maintaining topographic organisation in register across interconnected central visual pathways. Eur J Neurosci 2010;31:613-622.

100 Dalva MB, Takasu MA, Lin MZ, Shamah SM, Hu L, Gale NW, Greenberg ME: EphB receptors interact with NMDA receptors and regulate excitatory synapse formation. Cell 2000;103:945-956.

101 Lennington JB, Yang Z, Conover JC: Neural stem cells and the regulation of adult neurogenesis. Reprod Biol Endocrinol 2003;1: 99.

102 Alvarez-Buylla A, Garcia-Verdugo JM: Neurogenesis in adult subventricular zone. J Neurosci 2002;22:629-634.

103 Conover JC, Notti RQ: The neural stem cell niche. Cell Tissue Res 2008;331:211-224.

104 Riquelme PA, Drapeau E, Doetsch F: Brain micro-ecologies: neural stem cell niches in the adult mammalian brain. Philos Trans R Soc Lond B Biol Sci 2008;363:123-137.

105 Altman J: Autoradiographic and histological studies of postnatal neurogenesis. IV. Cell proliferation and migration in the anterior forebrain, with special reference to persisting neurogenesis in the olfactory bulb. J Comp Neurol 1969;137:433-457.

106 Doetsch F, Alvarez-Buylla A: Network of tangential pathways for neuronal migration in adult mammalian brain. Proc Natl Acad Sci USA 1996;93:14895-14900.

107 Doetsch F, Garcia-Verdugo JM, AlvarezBuylla A: Cellular composition and threedimensional organization of the subventricular germinal zone in the adult mammalian brain. J Neurosci 1997;17:50465061. 
108 Peretto P, Merighi A, Fasolo A, Bonfanti L: Glial tubes in the rostral migratory stream of the adult rat. Brain Res Bull 1997;42:921.

-109 Gritti A, Bonfanti L, Doetsch F, Caille I, Alvarez-Buylla A, Lim DA, Galli R, Verdugo JM, Herrera DG, Vescovi AL: Multipotent neural stem cells reside into the rostral extension and olfactory bulb of adult rodents. J Neurosci 2002;22:437-445.

110 Luskin MB: Restricted proliferation and migration of postnatally generated neurons derived from the forebrain subventricular zone. Neuron 1993;11:173-189.

- 111 Lois C, Alvarez-Buylla A: Long-distance neuronal migration in the adult mammalian brain. Science 1994;264:1145-1148.

-112 Bovetti S, Bovolin P, Perroteau I, Puche AC: Subventricular zone-derived neuroblast migration to the olfactory bulb is modulated by matrix remodelling. Eur J Neurosci 2007;25:2021-2033.

113 Snapyan M, Lemasson M, Brill MS, Blais M, Massouh M, Ninkovic J, Gravel C, Berthod F, Gotz M, Barker PA, Parent A, Saghatelyan A: Vasculature guides migrating neuronal precursors in the adult mammalian forebrain via brain-derived neurotrophic factor signaling. J Neurosci 2009;29:41724188.

-114 Whitman MC, Fan W, Rela L, RodriguezGil DJ, Greer CA: Blood vessels form a migratory scaffold in the rostral migratory stream. J Comp Neurol 2009;516:94-104.

- 115 Wichterle H, Garcia-Verdugo JM, AlvarezBuylla A: Direct evidence for homotypic, glia-independent neuronal migration. Neuron 1997; 18:779-791.

-116 Jankovski A, Sotelo C: Subventricular zone-olfactory bulb migratory pathway in the adult mouse: cellular composition and specificity as determined by heterochronic and heterotopic transplantation. J Comp Neurol 1996;371:376-396.
117 Murase S, Horwitz AF: Deleted in colorectal carcinoma and differentially expressed integrins mediate the directional migration of neural precursors in the rostral migratory stream. J Neurosci 2002;22:3568-3579.

118 Wu W, Wong K, Chen J, Jiang Z, Dupuis S, Wu JY, Rao Y: Directional guidance of neuronal migration in the olfactory system by the protein Slit. Nature 1999;400:331-336.

119 Ng KL, Li JD, Cheng MY, Leslie FM, Lee AG, Zhou QY: Dependence of olfactory bulb neurogenesis on prokineticin 2 signaling. Science 2005;308:1923-1927.

120 Paratcha G, Ibanez CF, Ledda F: GDNF is a chemoattractant factor for neuronal precursor cells in the rostral migratory stream. Mol Cell Neurosci 2006;31:505-514.

121 Chiaramello S, Dalmasso G, Bezin L, Marcel D, Jourdan F, Peretto P, Fasolo A, De Marchis S: BDNF/TrkB interaction regulates migration of SVZ precursor cells via PI3-K and MAP-K signalling pathways. Eur J Neurosci 2007;26:1780-1790.

122 Katakowski M, Zhang Z, de Carvalho AC, Chopp M: EphB2 induces proliferation and promotes a neuronal fate in adult subventricular neural precursor cells. Neurosci Lett 2005;385:204-209.

123 Bush JO, Soriano P: Ephrin-B1 regulates axon guidance by reverse signaling through a PDZ-dependent mechanism. Genes Dev 2009;23:1586-1599.

124 Nam SC, Kim Y, Dryanovski D, Walker A, Goings G, Woolfrey K, Kang SS, Chu C, Chenn A, Erdelyi F, Szabo G, Hockberger P, Szele FG: Dynamic features of postnatal subventricular zone cell motility: a twophoton time-lapse study. J Comp Neurol 2007;505:190-208.

125 Gale NW, Yancopoulos GD: Ephrins and their receptors: a repulsive topic? Cell Tissue Res 1997;290:227-241.

126 Bruckner K, Pasquale EB, Klein R: Tyrosine phosphorylation of transmembrane ligands for Eph receptors. Science 1997;275: 1640-1643.
127 Garzotto D, Giacobini P, Crepaldi T, Fasolo A, De Marchis S: Hepatocyte growth factor regulates migration of olfactory interneuron precursors in the rostral migratory stream through Met-Grb2 coupling. J Neurosci 2008;28:5901-5909.

128 Kong H, Boulter J, Weber JL, Lai C, Chao MV: An evolutionarily conserved transmembrane protein that is a novel downstream target of neurotrophin and ephrin receptors. J Neurosci 2001;21:176-185.

129 Cang J, Kaneko M, Yamada J, Woods G, Stryker MP, Feldheim DA: Ephrin-As guide the formation of functional maps in the visual cortex. Neuron 2005;48:577-589.

130 Cang J, Wang L, Stryker MP, Feldheim DA: Roles of ephrin-As and structured activity in the development of functional maps in the superior colliculus. J Neurosci 2008;28: 11015-11023.

131 Triplett JW, Owens MT, Yamada J, Lemke G, Cang J, Stryker MP, Feldheim DA: Retinal input instructs alignment of visual topographic maps. Cell 2009;139:175-185.

132 Boyle M, Nighorn A, Thomas JB: Drosophila Eph receptor guides specific axon branches of mushroom body neurons. Development 2006;133:1845-1854.

133 Kaneko M, Nighorn A: Interaxonal Ephephrin signaling may mediate sorting of olfactory sensory axons in Manduca sexta. J Neurosci 2003;23:11523-11538.

134 Coate TM, Swanson TL, Proctor TM, Nighorn AJ, Copenhaver PF: Eph receptor expression defines midline boundaries for ephrin-positive migratory neurons in the enteric nervous system of Manduca sexta. J Comp Neurol 2007;502:175-191.

135 Coate TM, Wirz JA, Copenhaver PF: Reverse signaling via a glycosyl-phosphatidylinositol-linked ephrin prevents midline crossing by migratory neurons during embryonic development in Manduca. J Neurosci 2008;28:3846-3860. 